Images $\ln .$.

\title{
Mediastinal mass
}

\author{
Umar Imran Hamid, J Mark Jones \\ Department of Cardiothoracic Surgery, Royal Victoria Hospital, Belfast, UK
}

Correspondence to Umar Imran Hamid, umar79@hotmail.com

\section{DESCRIPTION}

A 76-year-old patient presented with an incidental finding of an anterior mediastinal mass (figures 1 and 2) following investigations for pneumonia. The patient underwent median sternotomy and excision of the mass. The mass weighed $1 \mathrm{~kg}$ and measured $15 \times 14 \times 10 \mathrm{~cm}$. Histology revealed a grade $\mathrm{AB}$ thymoma of Masaoka stage II due to microscopic capsular invasion (figure 3 ). The patient made an uneventful postoperative recovery.

Thymoma is the most common tumour of the anterior mediastinum with an incidence of $0.10-0.18$ per 100000 . Overall, 35-50\% of patients with thymomas have myasthenia gravis, while $12 \%$ of patients with myasthenia gravis have a thymoma. Approximately $50 \%$ of individuals presenting with thymomas are clinically asymptomatic. Symptoms include chest pain, cough, dyspnoea and muscle fatigue (characteristic of myasthenia gravis). Less common symptoms, such as superior vena cava syndrome, phrenic nerve paralysis or recurrent laryngeal nerve involvement resulting in hoarseness, are indicative of malignant disease. The differential diagnoses of anterior mediastinal masses include lymphoma, retrosternal thyroid and germ cell tumours.

Patients with a suspected mediastinal mass as suggested in figure 1 should undergo CT scan. There were no features to suggest invasion into surrounding structures (figure 2) and in such cases complete surgical resection should be attempted (figure 4). Grade $A$ or $A B$ tumours of Masaoka

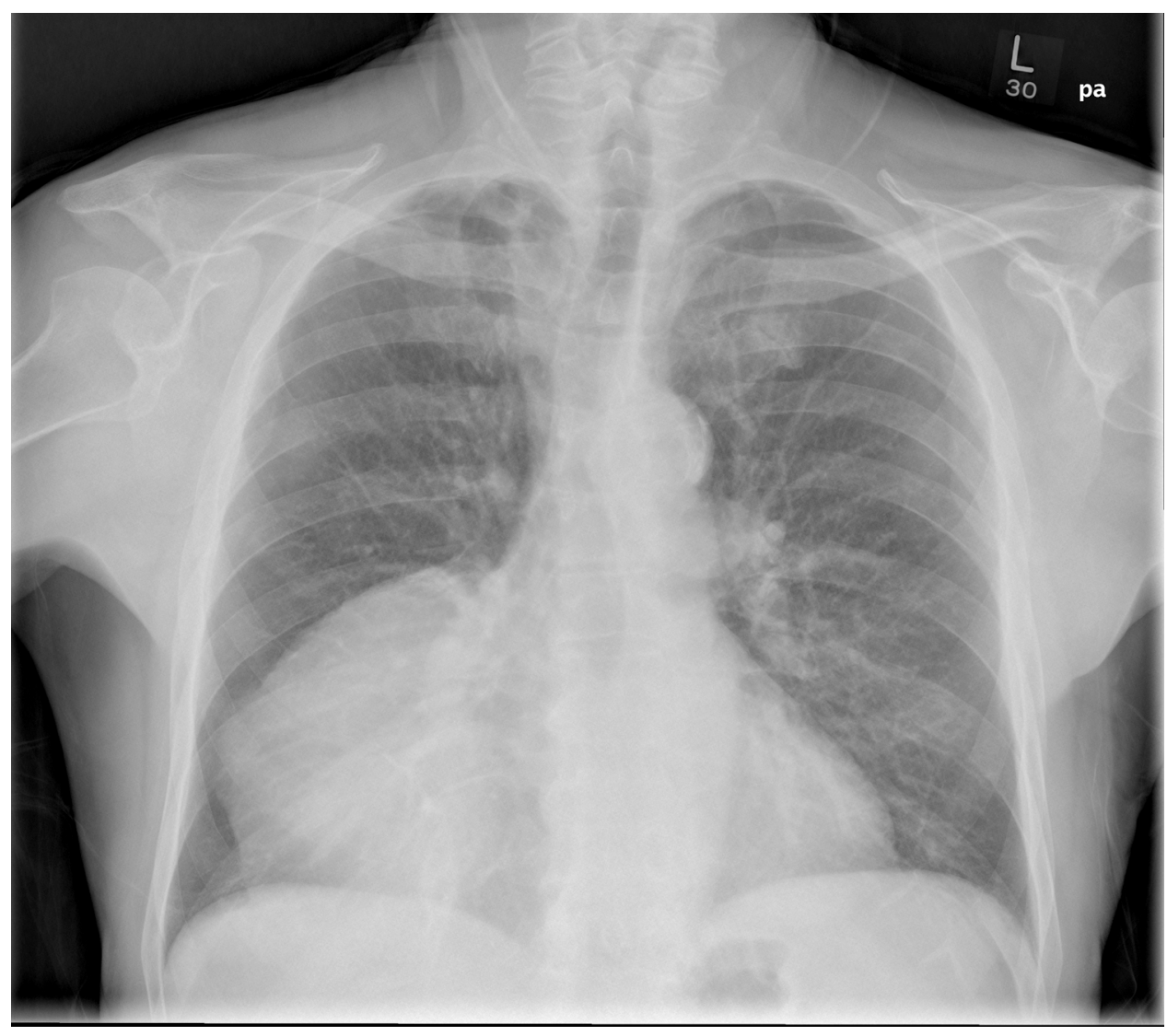

Figure 1 Chest x-ray showing mediastinal mass. 


\section{BMJ Case Reports}

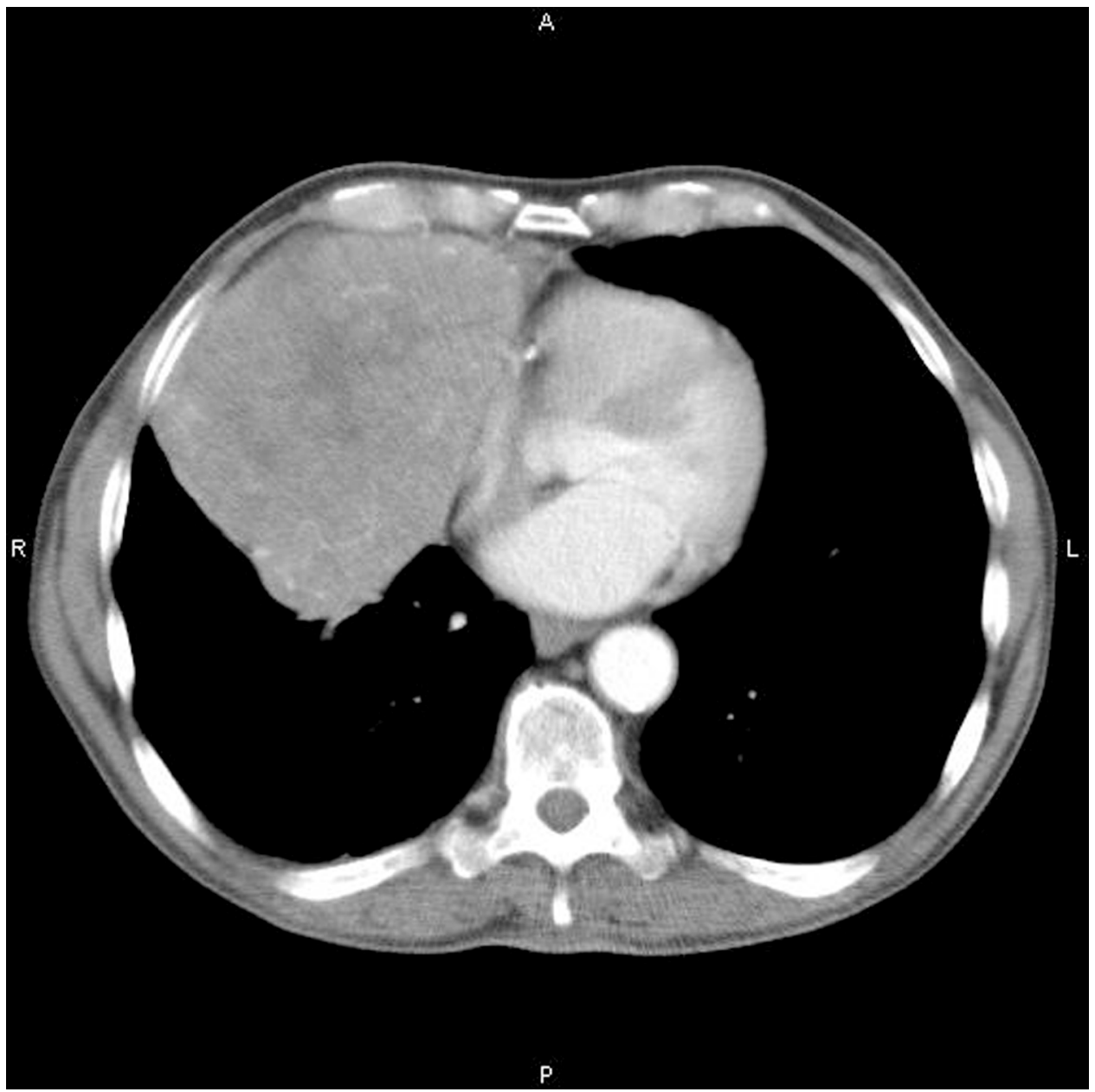




\section{BMJ Case Reports}

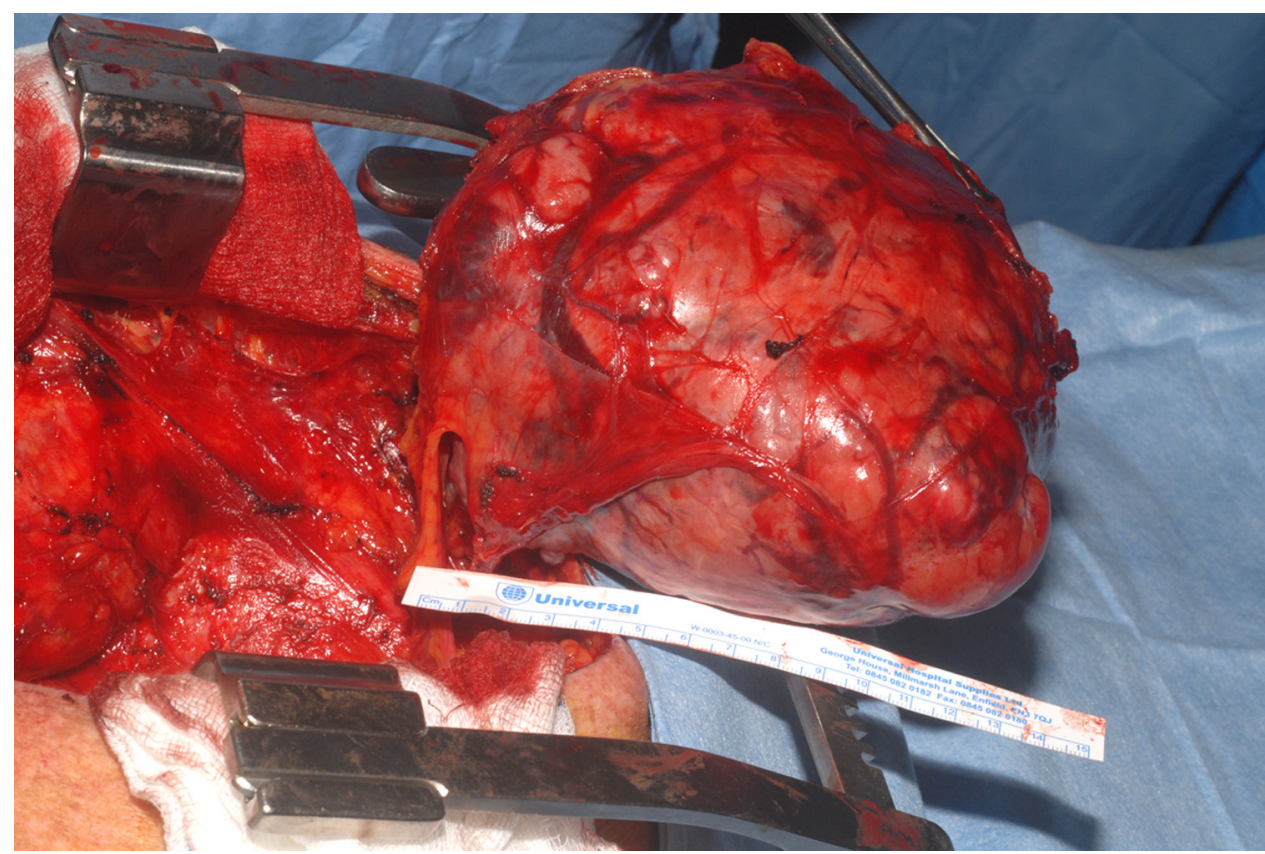

Figure 4 Thymoma completely excised.

stage I or II do not require adjuvant treatment. ${ }^{1}{ }^{2}$ However, neoadjuvant therapy should be considered for patients with large or invasive tumours. Surgical resection or debulking with adjuvant chemo-radiotherapy reduces the risk of recurrence in those with stage III (local invasion) or stage IV (distant metastases) disease. ${ }^{3}$ Predictors of long-term survival include complete surgical resection, stage, histological grade and size of tumour. Intra-thoracic recurrence is more likely in advanced stages but overall cause of death is unrelated to thymoma in $65 \%$ of patients.
Competing interests None.

Patient consent Obtained.

\section{REFERENCES}

1. Blumberg D, Port JL, Weksler B, et al. Thymoma: a multivariate analysis of factors predicting survival. Ann Thorac Surg 1995;60:908-13; discussion 914.

2. Singhal S, Shrager JB, Rosenthal DI, et al. Comparison of stages I-II thymoma treated by complete resection with or without adjuvant radiation. Ann Thorac Surg 2003;76:1635-41; discussion 1641-2.

3. Bacha EA, Chapelier AR, Macchiarini P, et al. Surgery for invasive primary mediastinal tumors. Ann Thorac Surg 1998;66:234-9.

\footnotetext{
This pdf has been created automatically from the final edited text and images.

Copyright 2010 BMJ Publishing Group. All rights reserved. For permission to reuse any of this content visit http://group.bmj.com/group/rights-licensing/permissions.

BMJ Case Report Fellows may re-use this article for personal use and teaching without any further permission.

Please cite this article as follows (you will need to access the article online to obtain the date of publication).

Hamid UI, Jones JM. Mediastinal mass. BMJ Case Reports 2010;10.1136/bcr.11.2009.2471, date of publication

Become a Fellow of BMJ Case Reports today and you can:

- Submit as many cases as you like

- Enjoy fast sympathetic peer review and rapid publication of accepted articles

- Access all the published articles

- Re-use any of the published material for personal use and teaching without further permission

For information on Institutional Fellowships contact consortiasales@bmjgroup.com

Visit casereports.bmj.com for more articles like this and to become a Fellow
} 